\title{
ANALISIIS FAKTOR - FAKTOR YANG MEMPENGARUHI KINERJA SISTEM INFORMASI AKUNTANSI PADA PT. BINA AREA PERSADA
}

\author{
Arik Puji Rahmawati ${ }^{1}$, Taudlikhul Afkar ${ }^{2}$ \\ Universitas PGRI Adi Buana Surabaya1,2 \\ Arikpuii22@gmail.com
}

\begin{abstract}
To analyze the factors that influence the performance of accounting information systems is a goal that researchers want to achieve. Retrieval of data by distributing questionnaires to respondents, then analyzing the data that has been obtained and then draw conclusions. The results of respondents' answers by using several tests such as validation tests and so on to support more valid results and the results can be justified. The results show that the Capability of Personnel Techniques, Management Support, User Engagement and User Education and Training affect the performance of the accounting information system
\end{abstract}

Keywords: TP Ability, User Engagement, Education and Training, User Management Support, Performance

\section{PENDAHULUAN}

Perkembangan teknologi informasi yang semakin pesat membuat masyarakat atau pelaku organisasi paling tidak merasakan dampak adanya perkembangan teknologi tersebut.Teknologi informasi dengan sistem yang terkomputerisasi sebagai penggerak telah mengubah segalanya. Kebanyakan organisasi bisnis saat ini telah beralih menggunakan komputer meskipun biaya investasi awalnya mahal.( Putri ,2018).Kedaan ini membuktikan bahwa bisnis pelayanan informasi semakin berkembang.

SIA mempunyai manfaat besar dalam pencapaian tujuan organisasi perusahaan. secara tipikal, Sistem dapat dinyatakan berhasil apabila memenuhi syarat tertentu yaitu : penggunaan dari sistem yang meningkat dan peresepsi pemakai atas kualitas systeem lebih baik dari sebelumnya serta kepuasan pengguna informasi meningkat.

Penelitian Hardiansyah (2015) diperoleh hasil yang menunjukkan hasil yaitu : keterlibatan pengguna mempunyai pengaruh dalam pengembangan sistem terhadap kinerja, SIA berpengaruh yaitu semakin tinggi keterlibatan pengguna dalam pengembangan sistem sebagai aktivitas-aktivitas yang dilakukan oleh pengguna dalam proses pengembangan sistem informasi.

Penelitian oleh Putri (2018) menguji faktor yang dapat meningkatkan kineja sistem informasi akuntansi, menunjukkan hasil yaitu: kemampuan pengguna mempunyai pengaruh terhadap SIA. Sedangkan menurut (Khaidir dan Susanti 2015) bahwa dalam penelitian tersebut menujukan bahwa pengguna dalam penelitian memiliki kemampuan personel yang baik yang artinya berpengaruh, dukungan manajemen puncak terhadap sistem informasi akuntansi memiliki kriteria penilaian yang baik,

Hasil pemaparan penelitian dari Hadriansyah, Putri, Khaidir dan Susanti terdapat perbedaan hasil yang sangat signifikan antara penelitian satu dengan penelitian yang lainnya, sedangkan persamaan dari penelitian tersebut yaitu kemampuan teknik personel berpengaruh tehadap kinerja SIA oleh karena itu penulis tertarik untu mengangkat judul "Pengaruh Kemampuan Teknik Personel dan Dukungan Manajemen Puncak Terhadap Kinerja Sistem Informasi Akuntansi".

\section{Perumusan Masalah}




\section{Journal of Sustainability Business Research (JSBR)}

Vol-1,Issue-1,Desember (JSBR)

\section{E-ISSN: 2746-8607}

http://jurnal.unipasby.ac.id/index.php/jsbr

1. Apakah kemampuan teknik personel berpengaruh terhadap kinerja SIA?.

2. Apakah keterlibatan pengguna dalam pengembangan sistem informasi akuntansi berpengaruh terhadap kinerja SIA?

3. Program pelatihan dan pendidikan pemakai berpengaruh terhadap kinerja SIA ?

\section{Tujuan Penelitian}

1. Untuk mengetahui pengaruh antara kamampuan teknik personel terhadap kinerja SIA.

2. Untuk mengetahui pengaruh antara dukungan manajemen puncak terhadap kinerja SIA.

3. Untuk mengetahui pengaruh antara pengembangan sistem informasi akuntansi berpengaruh terhadap kinerja SIA

\section{TELAAH PUSTAKA}

\section{Landasan teori}

Pada teori ini akan menjelaskan hal-hal yang melandasi penelitian pada tiap variabel.Technology Acceptance Model (TAM) adalah suatu model yang telah disusun oleh Davis (1989) yang menjelaskan bahwa penerimaan teknologi biasanya akan digunakan oleh pengguna teknologi.

Teori Technology Acceptance Model (TAM) sangat cocok digunakan untuk memprediksi pengaruh dan faktor penyebab kinerja SIA berjalan dengan baik.

\section{Kerangka Konseptual}

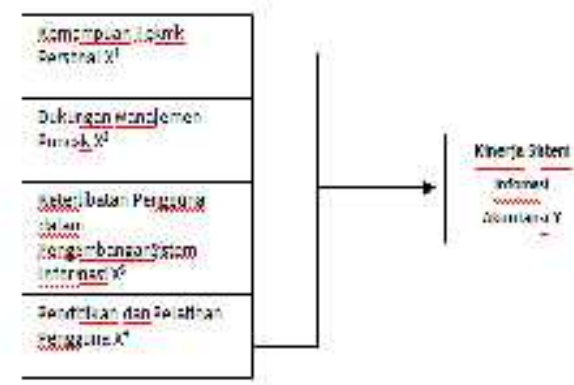

Kerangka konseptual diatas menjelaskan bahwa :

$X^{1}$ : Kemapuan Teknik Personel

$X^{2}$ : Dukungaan Manajemen Puncak

$X^{3}$ :Keterlibatan Pengguna dalam Pengembangan Sistem Informasi

$X^{4}$ :Pendidiikan dan Pelaatihan Pengguna

$Y$ : Kinerja SIA

\section{HIPOTESIS PENELITIAN}

H1 :Kemaampuan Teknik Personel berrpengaruh terhaadap Kineerja SIA Informasi Akuntansi.

H2 :Duukungan Manaajemen Punncak berpengaruh terhadap Kinerja SIA berpengaruh Terhadap Kinerja Sistem Informasi Akuntansi.

H3 :Keterlibatan Pengguna dalam Pengembangan Sistem Informasi berpengaruh Terhadap Kinerja SIA

H4 :Pendidikan dan Pelatihan Pengguna berpengaruh Terhadap Kinerja SIA

\section{METODE PENELITIAN}




\section{Journal of Sustainability Business Research (JSBR)}

Vol-1,Issue-1,Desember (JSBR)

\section{E-ISSN: 2746-8607}

\section{Populasi}

http://jurnal.unipasby.ac.id/index.php/jsbr

Penelitian menggunakan karyawan PT BINA AREA PERSADA bagian keuangan, SDM , Keamanan berjumlah 44 orang.

\section{Sampel}

sampel yang diambil merupakan keseluruhan responden yang berjumlah 44 , hal ini dilakukan untuk memenuhi kecukupan pengambilan data.

\section{TeknikPengambilan Sampel}

Teknik yang digunakan adalah teknik probabilitty dengan metode sampling jenuh.

\section{Variabel Penelitian}

variabel yang dipakai dalam penelitian ini adalah sebagai berikut :

Variabel Bebas:

1. KemampuanTeknik Personel $\left(X_{1}\right)$

2. Dukungan Manajemen $\left(X_{2}\right)$

3. Keterlibatan Pengguna $\left(X_{3}\right)$

4. Pendidikan dan Pelatihan Pengguna $\left(\mathrm{X}_{4}\right)$

VariabelTerikat

KinerjaSistemInformasiAkuntansi (Y)

\section{HASIL PENELITIAN}

Penelitian ini peneliti menggunakan sampel sebanyak 44 responden dari karyawan PT BINA AREA PERSADA. Karakterisitik respondennya pada penelitian ini dibagi menjadi tiga golongan, yaitu berdasarkan, umur, jenis kelamin dan pendidikan terakhir. Perhitungan frekuensi dan presentase dari karakteristik responden adalah berikut ini:

\section{Berdasarkan Jenis Kelamin}

karakteristik responden berdasarkan jenis kelamin memiliki presentase paling besar sebesar $59,09 \%$ yaitu karyawan yang berjenis kelamin perempuan yang berjumlah 26 orang. Sedangkan presentase karyawan yag berjenis kelamin laki-laki sebesar 40,91\%.

\section{Berdasarkan Umur}

Hasil penelitian menunjukkan bahwa hasil perhitungan dari karaktersitik responden berdasarkan umur yang memiliki presentase tertinggi sebesar 40,91\% yaitu karyawan yang berumur $26 \mathrm{~s} / \mathrm{d} 35$ tahun. Sedangkan presentase yang paling rendah sebesar $9,09 \%$ adalah karyawan yang berumur kurang dari 25 tahun.

\section{Pendidikan Terakhir}

Hasil perhitungan dari karaktersitik responden berdasarkan pendidikan terakhir yang memiliki presentase tertinggi sebesar $40,91 \%$ yaitu karyawan yang pendidikan terakhirnya SARJANA. Sedangkan presentase yang paling rendah sebesar 9,1\% adalah karyawan yang berpendidikan terakhir SMA.

\section{Analisis Data Penelitian Uji Validitas}

Berdasarkan hasil pengujian yang dilakukan, maka hasil pengujian tersebut pada menunjukkan bahwa semua item pada pernyataan diatas dinyatakan valid, sebab didapatkan hasil signifikan $<0,05$. Sehingga peneliti dapat melanjutkan pengujian ke tahap berikutnya.

\section{Uji Reliabilitas}

Hasil pengujian uji reliabilitas adalah berikut ini: 


\section{Journal of Sustainability Business Research (JSBR)}

Vol-1,Issue-1,Desember (JSBR)

\section{E-ISSN: 2746-8607}

http://jurnal.unipasby.ac.id/index.php/jsbr

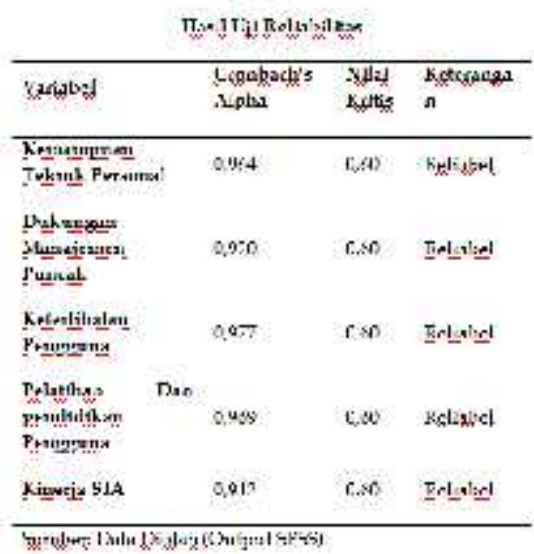

Dari table 4.11 diatas, diperoleh nilai koefisien reliabitas alpha Cronbach pada variabel kemampuan teknik personal sebesar 0,964, variabel dukungan personal sebesar 0,920, variabek keterlibatan pengguna sebesar 0,977, variabel pelatihan dan pendidikan pengguna sebesar 0,969 dan variabel kinerja SIA sebesar 0,912.Dari semua variabel menunjukkan nilai yang reliabel. Sehigga dapat dinyatakan semua variabel dinyatakan reliabel, sehingga kuesioner yang dibuat sebagai bahan acuan untuk penelitian dapat diterima responden dengan baik dan layak untuk dilanjutkan sebagai instrument penelitian.

\section{Pengujian Asumsi Klasik}

Uji Normalitas

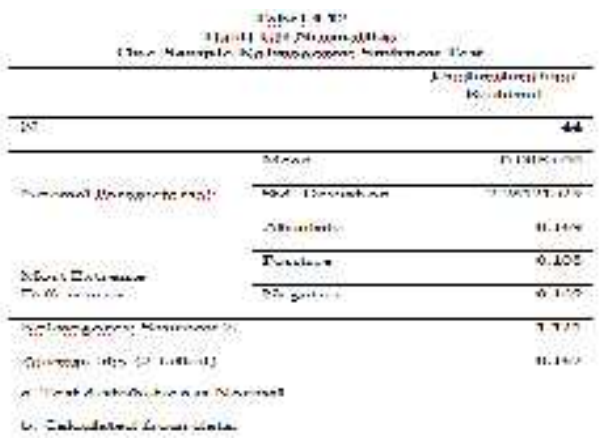

Berdasarkan hasil pengujian asumsi klasik untuk uji normalitas pada tabel 4.12 diperoleh nilai uji normalitas sebesar 0,162 >0,05. Maka dapat diyatakan bahwa model regresi yang digunakan berdistribusi normal, sehingga peneliti dapat melakukan uji selanjutnya.

\section{Uji Multikolinearitas}

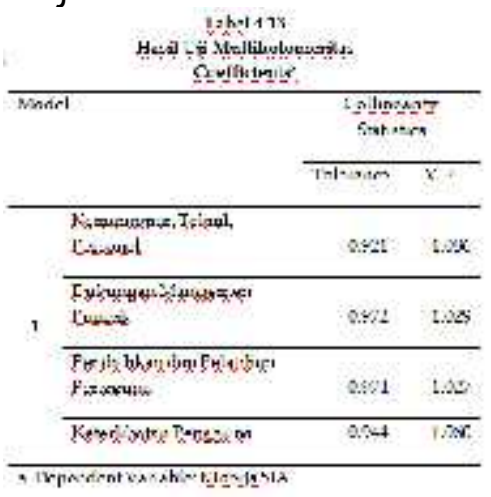

Hasil pengujian diperoleh nilai VIF variabel X1 sebesar 1,086, variabel X2 sebesar 1,029, variabel X3 


\section{Journal of Sustainability Business Research (JSBR)}

\section{Vol-1,Issue-1,Desember (JSBR)}

\section{E-ISSN: 2746-8607}

http://jurnal.unipasby.ac.id/index.php/jsbr

sebesar 1,027 dan variabel $X 4$ sebesar 1,060. Dari hasil tersebut diketahui bahwa semua variabel mempunyai nilai VIF < 10. maka dapat disimpulkan bahwa model regresi tersebut tidak terdapat masalah atau bebas dari uji multikolinearitas.

\section{Uji Heteroskedastisitas}

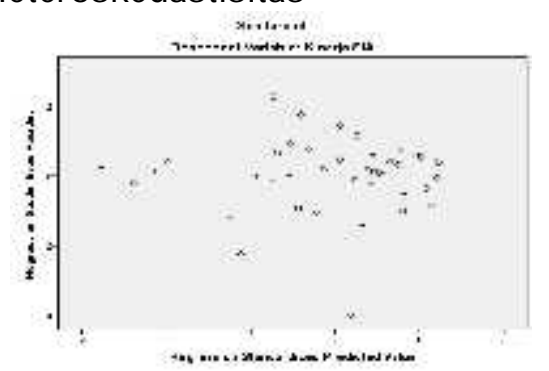

Gambar 4.1

Uji Hetrokedastisitas

Berdasarkan hasil pengujian asumsi klasik untuk uji heteroskedastisitas pada gambar scatterplot menunjukkan bahwa residu tidak membentuk pola tertentu dan residu berada diatas dan dibawah angka nol. Maka dapat dikatakan uji heteroskedastisitas yang dilakukan dengan uji scatterplot menyatakan bahwa model regresi dalam penelitian ini terbebas dari gejala heteroskedastisitas.

\section{Analisis Regresi Linear Berganda}

Berdasarkan hasil analisis tersebut didapatkan persamaan garis regesi adalah berikut ini:

$$
Y=0,176+0,133 X_{1}+0,200 X_{2}+0,082 X_{3}+0,098 X_{4}+3,373 e
$$

Keterangan :

1. Berdasarkan persamaan regresi tersebut didapatkan nilai konstan sebesar 0,176 yang menunjukkan apabila nilai variabel bebas sebesar nol maka variabel dependen terikat bernilai sebesar 0,176 satuan.

2. Koefisien Variabel kemampuan teknik personal $\left(X_{1}\right)$ didapatkan 0,133 dan memiliki nilai koefisien positif $(+)$, hal tersebut menunjukkan bahwa terdapat pengaruh yang sejalan antara variabel kemampuan teknik personal $\left(X_{1}\right)$ dengan variabel kinerja SIA $(Y)$, yang artinya setiap peningkatan nilai variabel kemampuan teknik personal $\left(X_{1}\right)$, maka nilai Variabel kinerja SIA $(Y)$ meningkat sebesar 0,133.

3. Koefisien Variabel dukungan manajemen puncak $\left(X_{2}\right)$ didapatkan nilai sebesar 0,200 dan memiliki nilai koefisien positif $(+)$, hal tersebut menunjukkan bahwa terdapat pengaruh yang sejalan, yang artinya setiap peningkatan nilai variabel dukungan manajemen puncak $\left(\mathrm{X}_{2}\right)$, maka nilai Variabel kinerja SIA $(Y)$ akan meningkat sebesar 0,200.

4. Koefisien Variabel keterlibatan pengguna $\left(X_{3}\right)$ didapatkan nilai sebesar 0,082 dan memiliki nilai koefisien positif $(+)$, yang artinya setiap peningkatan nilai variabel keterlibatan pengguna $\left(X_{3}\right)$, maka nilai Variabel kinerja SIA (Y) akan meningkat sebesar 0,082.

5. Koefisien Variabel pelatihan dan pendidikan pengguna $\left(X_{4}\right)$ didapatkan nilai sebesar 0,098 dan memiliki nilai koefisien positif $(+)$, yang artinya setiap peningkatan nilai variabel pelatihan dan pendidikan pengguna $\left(X_{4}\right)$, maka nilai Variabel kinerja SIA $(Y)$ akan meningkat sebesar 0,098.

\section{Koefisien Korelasi}

Adapun koefisen korelasi dan determinasi diperoleh hasil sebagai berikut : 
Journal of Sustainability Business Research (JSBR)

Vol-1,Issue-1,Desember (JSBR)

\section{E-ISSN: 2746-8607}

http://jurnal.unipasby.ac.id/index.php/jsbr

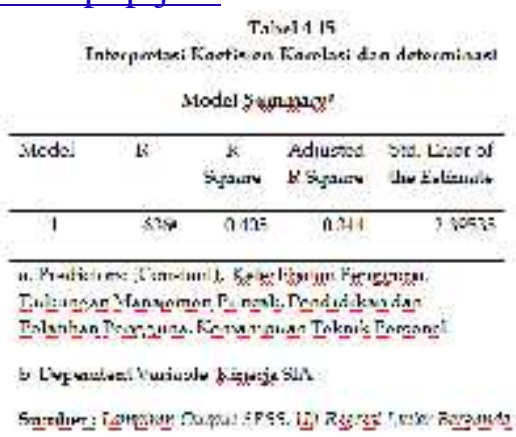

Berikut interpretasi tingkat hubungan koefisien korelasi :

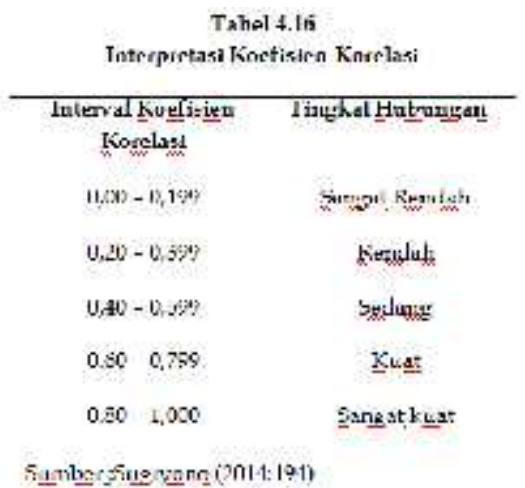

Berdasarkan analisis yang dilakukan menggunakan regresi linier berganda dperoleh nilai $R=0,636$. Berdasarkan klaster tabel interpretasi koefisien korelai pada tabel 4.15 diatas, maka dapat dinyatakan bahwa terdapat korelasi atau hubungan yang kuat antara variabel bebas dengan variabel terikat.

\section{Koefisien Determinasi}

Pada table diatas diketahui nilai $R$-Square $=0,405$. Hal ini menunjukkan bahwa bebas pada penelitian ini dapat mempengaruhi variabel kinerja SIA (Y) sebesar 40,5\%.

\section{Pengujian Hipotesis}

Uji Signifikan Parsial (Uji t) Hipotesis 1

\begin{tabular}{|c|c|c|c|c|c|}
\hline \multirow[t]{2}{*}{ Nosela } & \multicolumn{2}{|c|}{ 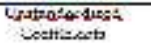 } & \multirow{2}{*}{ 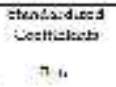 } & \multirow[t]{2}{*}{$\%$} & \multirow[t]{2}{*}{ sis. } \\
\hline & 7 & a. $r . .$. & & & \\
\hline insents & $n$ & $x .4$ & & 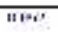 & 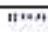 \\
\hline 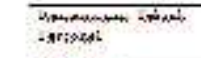 & uss & tes: & $24 n$ & $2: b$ & vas \\
\hline 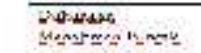 & $n=16$ & 11004 & 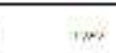 & $\cdots n$ & 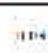 \\
\hline 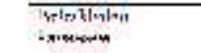 & un. & Niv & xis: & $2 k e$ & 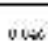 \\
\hline 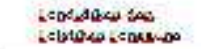 & wes & wote & $2.2 \%$ & $2.2 w$ & ves \\
\hline
\end{tabular}

Dari Tabel diatas pada pengujian uji t diketahui nilai kemampuan teknik personal sebesar 2,567 dan nilai sig sebesar 0,014 $(0,014<0,05)$.

Uji Signifikan Parsial (Uji t) Hipotesis 2

Dari hasil pengujian diketahui nilai t-hitung pada variabel dukungan $\mathrm{X} 2$ sebesar 2,246 dengan nilai sig sebesar $0,030(0,030<0,05)$.

\section{Uji Signifikan Parsial (Uji t) Hipotesis 3}

Hipotesis ketiga yang diajukan peneliti berbunyi "keterlibatan pengguna berpengaruh Terhadap Kinerja SIA". 
Journal of Sustainability Business Research (JSBR)

Vol-1,Issue-1,Desember (JSBR)

\section{E-ISSN: 2746-8607}

http://jurnal.unipasby.ac.id/index.php/jsbr

Pengujian hipotesis dilakukan dengan menggunakan software SPSS Versi 23.0. Berdasarkan dari hasil pengujian uji menunjukkan bahwa nilai t-hitung pada variabel keterlibatan pengguna sebesar 2,066 dengan nilai sig sebesar $0,046(0,046<0,05)$.

\section{Uji Signifikan Parsial (Uji t) Hipotesis 4}

Pada hipotesis keempat yang diajukan peneliti. Pengujian hipotesis dilakukan dengan menggunakan software SPSS Versi 23.0.Berdasarkan dari hasil pengujian uji t menunjukkan bahwa nilai t-hitung pada variabel X4 sebesar 2,210 dengan nilai sig sebesar 0,033 $(0,033<0,05)$.

\section{PEMBAHASAN}

Kemampuan teknik personal (X1) berpengaruh terhadap Variabel Kinerja SIA (Y).

Dari hasil pengujian hipotesis 1 dapat dinyatakan Hipotesis diterima. Yang artinya Kemampuan Teknik Personel berpengaruh positif dan signifikan terhadap Kinerja SIA. Pengaruh variabel X1 terhadap variabel $Y$ mempunyai nilai positif, yang artinya setiap peningkatan nilai variabel $X 1$, maka akan meningkatkan nilai variabel $Y$.

Dukungan manajemen puncak (X2) berpengaruh terhadap Variabel Kinerja SIA (Y).

Hasil pengujian hipotesis menggunakan Uji-t. diperoleh nilai sig. Dari hasil tersebut maka dapat dinyatakan Hipotesis diterima. Pengaruh dukungan manajemen puncak terhadap kinerja SIA mempunyai nilai positif, yang artinya setiap peningkatan nilai dukungan manajemen puncak, maka akan meningkatkan nilai kinerja SIA.

\section{Keteerlibatan Pengguuna (X3) berpeengaruh terhaadap Variabel Kineerja SIA (Y).}

Hasil pengujian hipotesis menggunakan Uji-t. diperoleh nilai sig. Dari hasil tersebut maka dapat dinyatakan Hipotesis diterima. Pengaruh variabel X3 terhadap variabel $Y$ mempunyai nilai positif, yang artinya setiap peningkatan nilai keterlibatan pengguna, maka akan meningkatkan nilai kinerja SIA.

Pendidikan dan pelatihan pengguna (X4) berpengaruh terhadap Variabel Kinerja SIA (Y).

Dari hasil pengujian hipotesis 4 dapat dinyatakan Hipotesis diterima. Yang artinya pelatihan dan pendidikan pengguna berpengaruh positif dan signifikan terhadap Kinerja Sistem Informasi Akuntansi.

\section{SIMPULAN}

1. Kemampuan Teknik Personel berpengaruh positif dan signifikan terhadap Kinerja Sistem Informasi Akuntansi pada PT. Bina Area Persada.

2. Dukungaan manajemen puncak berpengaruh terhadap Kinerja SIA pada PT. Bina Area Persada.yang artinya dengan adanya dukungan dari pimpinan, maka karyawan akan semakin bersemangat dalam bekerja, karena mereka merasa pekerjaannya dihargai oleh pimpinan.

3. Keterlibatan pengguna mempunyai pengaruh terhadap Kinerja SIA di PT. Bina Area Persada. Yang artinya bahwa karyawan ikut dilibatkan secara langsung pada pengembangan sitem informasi akuntansi sangat penting. Karena mereka diberi andil penting dalam pengembangan.

4. Variabel Pendidikan dan pelatihan pengguna berpengaruh positif dan signifikan terhadap Kinerja SIA pada PT. Bina Area Persada. Yang artinya bahwa pelatihan dan pendidikan dari karyawan sangat penting, dengan pendidikan yang tinggi, maka karyawan mempunyai cara berfikir dan menyelesaikan permasalahan dengan baik dibandingkan karyawan yang mempunyai pendidikan rendah.

\section{IMPLIKASI}

Hasil penelitian ini diharapkan dapat berguna untuk memberikan strategi dan solusi terhadap perusahaan agar lebih memperhatikan kinerja karyawan lebih baik dan perusahaan diuntungkan karenanya.

\section{KETERBATASAN PENELITIAN}

Peneliti mengalami keterbatasan dalam pengambilan kuisioner dikarenakan ada sesuatu hal yang tidak boleh diketahui peneliti dan hanya faktor-faktor tertentu saja. 


\section{Journal of Sustainability Business Research (JSBR)}

Vol-1,Issue-1,Desember (JSBR)

\section{E-ISSN: 2746-8607}

http://jurnal.unipasby.ac.id/index.php/jsbr

\section{DAFTAR RUJUKAN}

Basyari, Asyhar (2013), Hubungan antara Minat dan prestasi belajar sejarah dengan Kesadaran Sejarah Siswa MAN Yogyakarta III, Universitas Negeri Yogyakarta

Hardiansyah.2015, Analisis Faktor-Faktor yang Mempengaruhi Kinerja Sistem Informasi Akuntansi pada Rumah sakit Umum Daerah Sukoharjo, skripsi.Universitas Muhammadiyah Surakarta.

Irawati.2011, Analisis Faktor-Faktor yang Mempengaruhi Kinerja Sistem Informasi pada PT. Perkebunan Nusantara $\mathrm{XI}$ (persero), skripsi, Universitas Jember.

Khaidir.,Susanti, Neri. 2015. Analisis Faktor-Faktor yang Mempengaruhi Kinerja Sistem Informasi pada BANK Rakyat Indonesia Kantor Cabang Bengkulu.EkombisReview. UniversitasDehasen Bengkulu.

Putri.2018, Analisis Faktor-Faktor yang Mempengaruhi Kinerja Sistem Informasi Akuntansi pada rumah sakit PKU Muhammadiyah Surakarta dan Rumah Sakit PKU MuhammadiyahDelanggu, skripsi, Universitas Muhammadiyah Surakarta. 